\title{
P-equilibrium fertilization in an intensive dairy farming system: effects on soil-P status, crop yield and $P$ leaching
}

\author{
J. Verloop · J. Oenema $\cdot$ S. L. G. Burgers $\cdot$ \\ H. F. M. Aarts $\cdot$ H. van Keulen
}

Received: 9 October 2009/Accepted: 6 January 2010/Published online: 12 January 2010

(C) The Author(s) 2010. This article is published with open access at Springerlink.com

\begin{abstract}
In the coming decade, European dairy farms are obliged to realize a balance between phosphor (P) inputs to their farmland (in inorganic fertilizers and manure) and outputs (in crop products), the so-called P-equilibrium fertilization. The objective of the present study is to analyze the long-term effects of P-equilibrium fertilization on soil-P status (total soil-P and available soil-P), crop yield and $\mathrm{P}$ leaching on dry sandy soil, using data from experimental dairy farm 'De Marke', where P-equilibrium fertilization has been applied since 1989. For grassland, $P$ availability is expressed in P-Al and for arable land in Pw. Total and available $\mathrm{P}$ status were monitored in the upper topsoil (layer $0-0.2 \mathrm{~m}$ ). Total soil-P was also monitored in the lower topsoil (layer $0.2-0.4 \mathrm{~m}$ ) and in the subsoil (0.4-0.6 m). From 1989 to 2006, Pw and P-Al (means of all farmland) decreased by 26 and $25 \%$, respectively. In the same period, mean total-P content of the farmland decreased by $16 \%$. There was a large variation in initial P status (1989) of the various plots. The rate of decline in all soil-P indicators was positively correlated to their initial values. In plots with the lowest initial values, P status did not change, while in plots with high initial values it tended to stabilize at lower levels. At equilibrium-P fertilization,
\end{abstract}

J. Verloop $(\bowtie) \cdot$ J. Oenema · S. L. G. Burgers ·

H. F. M. Aarts · H. van Keulen

Plant Research International, PO Box 616, 6700 AP

Wageningen, The Netherlands

e-mail: koos.verloop@wur.nl
Pw is estimated to stabilize at 20 . This is lower than the recommended $\mathrm{P}$ status of Dutch soils used for maize cropping. $\mathrm{P}-\mathrm{Al}$ is estimated to stabilize at $30-40$, which corresponds to the current recommendations for grassland. The data show that at P-equilibrium fertilization, soil available-P status is higher in a maize-ley rotation than in permanent grassland. The decline in total $\mathrm{P}$ and available $\mathrm{P}$ did not affect crop yield, nor did it affect the $\mathrm{P}$ concentration in groundwater, but at ' $\mathrm{De}$ Marke', $\mathrm{P}$ emission to groundwater is generally low. The results obtained suggest that P-equilibrium fertilization can be compatible with efficient crop production.

Keywords Nutrient management .

Soil fertility · Phosphor - Groundwater .

Maize $\cdot$ Grassland $\cdot \mathrm{Pw} \cdot \mathrm{P}-\mathrm{Al}$

\section{Introduction}

At dairy farms, phosphor $(\mathrm{P})$ is an indispensable external input to replenish the $\mathrm{P}$ exported in products and the $\mathrm{P}$ emitted to the environment (Von Liebig 1841). During recent decades, however, $P$ inputs to dairy farms in purchased feed and fertilizer have increased disproportionally in comparison to outputs in milk and meat (Edwards and Withers 1998; Halberg 1999; Aarts et al. 2000; Watson et al. 2002; Pfimlin et al. 2006). Currently, P inputs into 
commercial dairy farms in the Netherlands amount to $25 \mathrm{~kg} \mathrm{ha}^{-1}$, while output with products is only $14 \mathrm{~kg} \mathrm{ha}^{-1}$ (Aarts et al. 2009). About $20 \mathrm{~kg} \mathrm{P}^{-1}$ is imported in feeds, purchased to meet animal feed requirements, in addition to home-grown crops. The remaining $5 \mathrm{~kg} \mathrm{ha}^{-1}$ is in inorganic fertilizer $\mathrm{P}$ (Aarts et al. 2009). The difference between $P$ inputs and outputs, i.e. the $\mathrm{P}$ surplus, may vary in Europe from 10 to $72 \mathrm{~kg} \mathrm{ha}^{-1}$ (Pfimlin et al. 2006). The high $\mathrm{P}$ input in external feeds results in a high manure $P$ production, most of which is applied to the farmland, often in combination with fertilizer-P application. This may lead to higher $\mathrm{P}$ inputs to the farmland than crops are able to absorb and thus to a soil-P surplus (Aarts et al. 2000).

A soil-P surplus contributes to the build-up of $\mathrm{P}$ in agricultural soils and may ultimately lead to $P$ saturation of the soil, resulting in an increased risk of leaching to groundwater (Van der Zee and Van Riemsdijk 1988; Hooda et al. 2001; Kronvang et al. 2007). In areas with steep slopes also surface runoff contributes to $\mathrm{P}$ transport to aquatic systems (Haygarth et al. 1998). Enrichment of water bodies with $P$ causes eutrophication and thus negatively affects the quality of aquatic ecosystems (Tunney et al. 1997; Hosper 1997; Ulén et al. 2007). The European Water Framework Directive (WFD) aims at preserving water quality by reducing pollution (Anonymous 2000). With respect to P, WFD urges EU-member states to implement regulations preventing $\mathrm{P}$ accumulation in agricultural soils, notably in regions with intensive animal production (Anonymous 2000; Neeteson et al. 2006). Therefore, intensive dairy farms are obliged to balance the $\mathrm{P}$ input to farmland through manure and inorganic fertilizer with $\mathrm{P}$ output in crop products, i.e. by applying P-equilibrium fertilization.

The $\mathrm{P}$ concentration in manure, and hence the $\mathrm{P}$ application rates to farmland, can be reduced through feeding the cattle with concentrates low in $\mathrm{P}$, without affecting herd performance (Morse et al. 1992; Valk and Sebek 1999). When this strategy does not reduce manure $\mathrm{P}$ inputs sufficiently, the surplus manure has to be exported from the farm to be able to comply with P-equilibrium fertilization.

However, great uncertainty exists about the longterm effects of P-equilibrium fertilization on plant available soil-P. The level of plant-available $\mathrm{P}$ might ultimately decrease to such an extent that the $P$ requirement of crops may not be fully satisfied anymore (e.g. Leigh and Johnston 1986). To maintain an agronomically acceptable level of available P, farmers' practice and fertilizer recommendations suggest that a supply of $10-30 \mathrm{~kg} \mathrm{P} \mathrm{ha}^{-1}$ year $^{-1}$ is required to compensate for the continuous transfer of plant available soil-P to non-available $\mathrm{P}$ through leaching and fixation (Aarts et al. 2000; Anonymous 2002; Neeteson et al. 2006). The observation in a number of field experiments that for optimum crop production $\mathrm{P}$ input should exceed $\mathrm{P}$ output may support the suggestion that part of supplied $\mathrm{P}$ cannot be utilized by the crop, because it has been transferred to the non-available $\mathrm{P}$ pool (Gallet et al. 2003, Neeteson et al. 2006, Syers et al. 2008). Syers et al. (2008), however, argue that the importance of $\mathrm{P}$ fixation is often overestimated, due to biased interpretation of the results of field trials. They point at (1) investigations in which a weak yield response to $\mathrm{P}$ application was interpreted as an effect of low availability of supplied $\mathrm{P}$, whereas it was probably caused by saturation of crop needs, (2) the short response time of experiments that leads to underestimation of the long-term recovery of $\mathrm{P}$ by crops, and (3) insufficient attention for residual effects of earlier supplies of P. Deliberately applying more P than is required for maximum crop production to maintain an adequate level of available soil-P, may thus not always be necessary, as is often presumed.

It should be noted that when P-equilibrium fertilization is applied to soils with a high $\mathrm{P}$ status, $\mathrm{P}$ may still move to the subsoil or leach to groundwater (Van der Zee and Van Riemsdijk 1988; Schippers et al. 2006). If this is the case, $P$ mining, i.e. deficit $P$ fertilization, may be required to restrict $\mathrm{P}$ leaching (Koopmans et al. 2004). For soils with different $P$ status, subjected to P-equilibrium fertilization, data on P losses to the subsoil (layers below the root zone) and groundwater are scarce (Koopmans 2004).

Uncertainties thus still exist on the extent to which $\mathrm{P}$ surplus applications are needed and on how soil-P status and crop yields will respond to long-term P-equilibrium fertilization. The aim of the current study is to evaluate the effects of P-equilibrium fertilization in a dairy production system on: (1) the development of the soil-P status, (2) crop yields, and (3) P losses to subsoil and groundwater. The evaluation is based on data that have been collected at experimental dairy farm 'De Marke', where P-equilibrium fertilization is tested at farm scale. 


\section{Materials and methods}

\section{Experimental farm 'De Marke'}

\section{Site characteristics}

'De Marke', established in 1989 and fully operational since 1992 (Aarts et al. 2000), is situated in the eastern part of the Netherlands on very light sandy soil, characterized by a $0.25-0.30 \mathrm{~m}$ anthropogenic upper layer, with an average organic matter content of $4.8 \%$ and a bulk density of $1300 \mathrm{~kg} \mathrm{~m}^{-3}$, overlying a layer of yellow sand, very low in organic matter and hardly penetrable by roots (Aarts et al. 2000). At the start of 'De Marke', the soil was ploughed to a depth of $0.3 \mathrm{~m}$ to homogenize the topsoil. Soil water content is usually at field capacity in spring ( 0.18 g per g oven-dry soil), decreasing in mid-summer to $0.12 \mathrm{~g}$ per $\mathrm{g}$ oven-dry soil under normal rainfall conditions and to 0.10 $0.05 \mathrm{~g}$ per g oven-dry soil in dry summers. Groundwater depth is 1-3 m below soil surface during summer and $0-1 \mathrm{~m}$ during winter. In the research period, precipitation (mean annual $788 \mathrm{~mm}$ ) was on average rather evenly distributed throughout the year, with a minimum of $47 \mathrm{~mm}$ in April and a maximum of $82 \mathrm{~mm}$ in July. As the groundwater level is relatively deep and the water holding capacity of the topsoil is low, available water is often limiting plant growth during the summer period.

\section{Farm layout}

The experimental farm was established to test an environmentally and economically sustainable dairy production system on a dry sandy soil, with a milk production intensity of at least $12,000 \mathrm{~kg} \mathrm{ha}^{-1}$ (a common level in the Netherlands). The objective was to meet environmental standards for $\mathrm{N}$ and
P. Environmental standards were translated into corresponding surpluses that were used as boundary conditions for farm performance. For $\mathrm{P}$, the maximum surplus was calculated to be $0.45 \mathrm{~kg} \mathrm{P} \mathrm{ha}^{-1}$ year $^{-1}$ corresponding to the Dutch surface water threshold value: $0.15 \mathrm{mg} \mathrm{P}^{-1}$. To realize this, a P-equilibrium fertilization strategy was applied (Aarts et al. 1992).

To ensure that a zero $\mathrm{P}$ surplus was realized, $\mathrm{P}$ inputs were adjusted to the expected $\mathrm{P}$ output in milk and meat. To satisfy feed (energy and protein) requirements, with minimum use of concentrates, production of home-grown feeds was maximized through optimal fertilizer management.

The farm area (55 ha) is divided into permanent grassland (11 ha) and two grassland-arable crop rotations (Rot I and Rot II, Table 1). The rotation scheme of the arable phase was slightly modified in the course of time. From 1993 until 1996, fodder beet was the first arable crop to succeed the grassland phase. From 1996 until 1999, maize was the only arable crop, after which triticale and wheat were introduced as the last crop in the arable phase. During the cultivation of maize, Italian ryegrass was sown in early summer as a catch crop between the maize rows. A total of 31 ha of grassland was available for grazing by 80 cows and young stock. To prevent problem swapping, environmental goals for the farming system were to be met without exporting slurry. See Verloop et al. (2006) for further details on the farm layout.

\section{Farm fertilizer strategy}

Fertilizer management aimed at matching supply and crop demand. No inorganic P fertilizer was used, because it was hypothesized that crop-P requirements could be met with manure-P only.
Table 1 Farm plan of 'De Marke' (ha) and crop sequence of the two rotation regimes

\begin{tabular}{ll}
\hline Component & Average \\
\hline Total area & 55 \\
Permanent grassland & 11 \\
Ley & 20 \\
Maize & 17 \\
Triticale, wheat & 7 \\
Rotation I & 3 Years grassland $\rightarrow>3$ years arable crops $->$, etc. \\
Rotation II & 3 Years grassland $\rightarrow>5$ years arable crops $->$, etc. \\
\hline
\end{tabular}


Annual manure-P supply was related to the phase of the rotation (Table 2). Manure-N supply was adjusted to meet $\mathrm{N}$ requirements in all phases of the rotation, which was high in ley and low in maize. Consequently, in the crop rotations, $\mathrm{P}$ supply to ley exceeded crop $\mathrm{P}$ uptake, resulting in a positive $\mathrm{P}$ balance during the ley phase, while it was lower than crop $\mathrm{P}$ uptake in the arable phase, resulting in a negative $\mathrm{P}$ balance. The overall result of manure $\mathrm{P}$ supply in the crop rotations was a zero $\mathrm{P}$ surplus. The $\mathrm{N}$ requirement of permanent grassland was constant over time and, consequently, so was the $\mathrm{N}$-manure supply and P-manure supply, resulting in a lower average annual $\mathrm{P}$ supply than in ley. $\mathrm{P}$ input in atmospheric deposition was estimated to be $1 \mathrm{~kg} \mathrm{ha}^{-1}$ year $^{-1}$ (Aarts 2000).

On grassland, fertilizer application was restricted to the period March 15 until August 1. Catch crops, grown in the arable phase, were ploughed-in during the first week of March. On maize, fertilizer was applied at the end of April, just before sowing. From early 2003 onwards, slurry was fermented before application.

Data collection

The total area of 'De Marke' was divided in 24 fields and each field was sub-divided in two or three plots of about 1 ha (resulting in 59 plots). For each of the 24 fields, management, nutrient flows and yields were monitored since 1993. Rate, timing and method of manure application, and dates of harvesting/cutting, grazing, re-sowing and plowing were monitored. Organic matter flows (harvested crop material and applied slurry) were measured by weighing and the related nutrient flows were quantified on the basis of chemical analyses of representative samples. Fresh grass consumption by grazing cattle was calculated by estimating standing biomass just before and after grazing and correcting for growth during grazing. $\mathrm{P}$ in excreta voided during grazing was estimated from feed intake, by subtracting (1) P output in milk and meat and (2) $\mathrm{P}$ excretion indoors. $\mathrm{P}$ output in milk was derived from chemical analyses of milk and monitoring of milk production.

Soil samples of the upper layer of the rooting zone (0.2 $\mathrm{m}$ upper topsoil) were taken in each of the 59 plots, at the start of 'De Marke' in 1989 and annually from 1994 to 2006 (Aarts et al. 2000). In each plot, 40 cores were mixed into a composite sample. Total soil$\mathrm{P}$ was determined, using destruction with Fleischman acid (Murphy and Riley 1962). Plant-available P was expressed as Pw (Table 3) for arable crops (Van der Paauw 1971) and P-Al (Table 3) for grassland (Van der Paauw 1956) in accordance with their use as

Table 2 Phosphorus supply $\left(\mathrm{kg} \mathrm{ha}^{-1}\right)$ to maize, triticale and grassland at 'De Marke'; means for 1993-2006

\begin{tabular}{|c|c|c|c|c|c|c|c|}
\hline \multirow[t]{2}{*}{ Land use } & \multicolumn{3}{|c|}{ Arable phase } & \multicolumn{3}{|c|}{ Grassland phase } & \multirow[t]{2}{*}{ Continuous } \\
\hline & 1 st year & 2nd year & $>2$ nd year & 1st year & 2nd year & $>2$ nd year & \\
\hline Rotation I & 5 & 12 & 22 & 42 & 46 & 45 & - \\
\hline Rotation II & 12 & 15 & 21 & 41 & 40 & 36 & - \\
\hline Permanent grassland & - & - & - & - & - & - & 35 \\
\hline
\end{tabular}

Table 3 Soil analyses for $\mathrm{P}$

\begin{tabular}{|c|c|c|c|}
\hline P-test & Metho0064 & Unit & References \\
\hline $\mathrm{Pw}$ & $\begin{array}{l}\text { 1:60 (Volume/volume), extraction with water, } \\
22 \mathrm{~h} \text { incubation, } 1 \mathrm{~h} \text { shaking }\end{array}$ & $\mathrm{mg} \mathrm{P}_{2} \mathrm{O}_{5}$ per litre soil & Van der Paauw (1971) \\
\hline P-Al & $\begin{array}{l}\text { 1:20 (Dry weight/volume), extraction with } 0.1 \text { ammonium } \\
\text { lactate }+0.02 \mathrm{~m} \text { hydrochloric acid, } \mathrm{pH} 3.7,1.5 \mathrm{~h} \text { shaking }\end{array}$ & mg $\mathrm{P}_{2} \mathrm{O}_{5}$ per $100 \mathrm{~g}$ dry soil ${ }^{\mathrm{a}}$ & Van der Paauw (1956) \\
\hline Total soil-P & $\begin{array}{l}\text { Destruction with Fleischman acid; spectrophotometric } \\
\text { determination, following coloring with ammonium } \\
\text { molybdate, antimone and ascorbic acid }\end{array}$ & mg $\mathrm{P}_{2} \mathrm{O}_{5}$ per $100 \mathrm{~g}$ dry soil ${ }^{\mathrm{a}}$ & Murphy and Riley (1962) \\
\hline
\end{tabular}

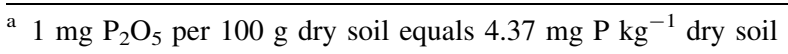


indicators in Dutch fertilizer recommendations. $\mathrm{Pw}$ is an indicator for $\mathrm{P}$ that is readily available for arable crops (maize) and $\mathrm{P}-\mathrm{Al}$ is an indicator for $\mathrm{P}$ that comes available during the growing season for grassland, respectively (Van der Paauw 1956, 1971; Neyroud and Lisscher 2003). Samples from the 0.2$0.4 \mathrm{~m}$ layer, the lower layer of the rooting zone (lower topsoil; 31 plots) and the 0.4-0.6 m layer, the layer below the rooting zone (subsoil; six plots), selected randomly from all plots, were collected at several occasions between 1991 and 2004. In 1989 and from 1994 to 2006 at the end of each year, the upper groundwater was sampled at 170 points, distributed proportionally per field on the basis of the area. Boreholes were constructed up to $0.8 \mathrm{~m}$ below the groundwater table. Water, sampled with a well-screen, using a suction pump, was directly filtered and acidified with sulphuric acid. P concentration was determined colorimetrically (Boumans et al. 2001).

\section{Data analyses}

We analyzed effects of equilibrium fertilization by evaluation of (1) development of soil-P status (upper topsoil), (2) crop yields and (3) losses to subsoil and groundwater. For that purpose, we first analyzed the variability in initial soil-P status: $\mathrm{P}_{\text {init }}, \mathrm{Pw}_{\text {init }}$ and $\mathrm{P}-\mathrm{Al}_{\text {init }}$.

\section{Development of soil-P status}

The development of the P status in the upper topsoil was analyzed at three scales: (1) farm, (2) land use: permanent grassland, Rot I and Rot II and (3) plots. Effects at farm scale were analyzed by assessment of total soil-P and plant-available P (means of all plots). Effects at land use scale (all uses subjected to P-equilibrium fertilization) were analyzed by comparing the $\mathrm{P}$ status as observed since the year 2000. We compared mean total soil-P and plant-available $\mathrm{P}$ of plots in permanent grassland, with means of plots in Rot I and means of plots in Rot II. The effects of land use type on $\mathrm{P}$ status were corrected for (rather small) differences in initial P status (values in 1989).

At the start of 'De Marke', soil-P status varied from rather low to very high, depending on manure application rates in the period of commercial exploitation before its establishment. This allows analysis of effects of P-equilibrium fertilization on plots with different initial soil-P status. For total $\mathrm{P}, \mathrm{Pw}$ and $\mathrm{P}-\mathrm{Al}$, the relationship between initial status and their development was explored for all individual plots, using the measurements in the course of time. Eight of the 59 plots were excluded from the analysis, since they were not part of the 'De Marke' system during the entire research period (1989-2006). P dynamics were explored for each plot by linear regression analysis. This resulted in estimates of the initial $\mathrm{P}$ status and the rates of decline $(\mathrm{dP} / \mathrm{dt}, \mathrm{dPw} / \mathrm{dt}$ and $\mathrm{dP}-\mathrm{Al} / \mathrm{dt}$ ) for each individual plot. We expected the rate of decline in plots with high initial status to level off in the course of time. To test this hypothesis we also fitted the dynamics with an exponential model (non-linear regression). Next, the relationship between estimates of the initial status and estimates of the rate of decline was analyzed by linear regression.

\section{Crop yields}

Effects of P-equilibrium fertilization on crop yields were analyzed at two scales: (1) farm and (2) field. Effects at farm scale were analyzed by assessment of $\mathrm{P}$ uptake and dry matter yield (means of all fields) in the course of time. At the field scale, the relation was explored between $\mathrm{P}$ status in the upper topsoil and yield for the main crops: grass and maize. The effect of $\mathrm{P}$ status on maize production for the period 1994 to 2006 was explored at the field scale by linear regression of average $\mathrm{Pw}$ values (arithmetic average of $\mathrm{Pw}$ values of the plots belonging to the field) on maize $\mathrm{P}$ uptake and dry matter yield. The same procedure was followed for $\mathrm{P}-\mathrm{Al}$ in grassland. Effects of temperature, radiation and moisture availability and their interactions may result in different production potentials each year. Consequently, temporal variability in weather conditions may lead to differences in crop yields that could interfere with the analysis of crop response to $\mathrm{P}$ status. To take this variability into account, three weather types were defined with their corresponding production potential: weather type 1 (WT1) with low production potential, weather type 2 (WT2) with intermediate production potential and weather type 3 (WT3) with high production potential. For each year, potential annual grass production was simulated with the weather-based model CNGRASS (Conijn 2005), and potential maize production with the model 
WOFOST (Supit et al. 1994), based on daily precipitation, radiation and temperature during the growing seasons. On the basis of calculated potential production, years were categorized as WT1, WT2 or WT3. Effects of P status on crop yield were analyzed for years with the three weather types separately.

\section{Losses to subsoil and groundwater}

Effects on P losses to the lower topsoil and the subsoil were analyzed at two scales: (1) farm and (2) plot. Effects at farm scale were analyzed by comparing the change in total soil-P in the upper topsoil (means of all plots) over time with the change in the lower topsoil and the subsoil (means of plots). At the plot scale the same procedure was followed for individual plots.

Effects on groundwater were analyzed at two scales: (1) farm and (2) field. Effects at the farm scale were analyzed by assessment of the $\mathrm{P}$ concentration in groundwater (means of groundwater samples). Effects at field scale were analyzed by exploring the relationship between soil-P status and $\mathrm{P}$ concentration in groundwater for the years 1994-2006. P concentration in groundwater was calculated as the arithmetic mean of the values observed in the (3-6) boreholes per field. Mean soil-P status was calculated as the arithmetic mean of the values of the plots of each individual field.

\section{Results}

Development of soil-P status

For total soil-P, $\mathrm{Pw}$ and $\mathrm{P}-\mathrm{Al}$, the initial $\mathrm{P}$ status in the upper topsoil was 169 (range 116-289), 57 (range 26-141) and 75 (range 38-142), respectively. High and low values were evenly distributed over Permanent Grassland, Rot I and Rot II. The distributions of $\mathrm{P}_{\text {init }}, \mathrm{Pw}_{\text {init }}$ and $\mathrm{P}-\mathrm{Al}_{\text {init }}$ were all skewed (Fig. 1). $\mathrm{P}_{\text {init }}$, $\mathrm{Pw}_{\text {init }}$ and $\mathrm{P}-\mathrm{Al}_{\text {init }}$ were highly correlated, with correlation coefficients of 0.81 for $\mathrm{P}_{\text {init }}$ and $\mathrm{Pw}_{\text {init }}$, 0.92 for $\mathrm{P}_{\text {init }}$ and $\mathrm{P}-\mathrm{Al}_{\text {init }}$ and 0.86 for $\mathrm{Pw}_{\text {init }}$ and $\mathrm{P}-\mathrm{Al}_{\text {init }}$. The $\mathrm{P}$ status of the plots can thus be characterised in terms of either total soil-P, $\mathrm{Pw}$ or P-Al. In the layers $0.2-0.4 \mathrm{~m}(n=31)$ and $0.4-0.6 \mathrm{~m}$ $(n=6), \mathrm{P}_{\text {init }}(1991)$ was $94 \pm 27.2$ and $28 \pm 5.9$ (mean \pm standard deviation), respectively, i.e. appreciably lower than in the top $0.2 \mathrm{~m}$.
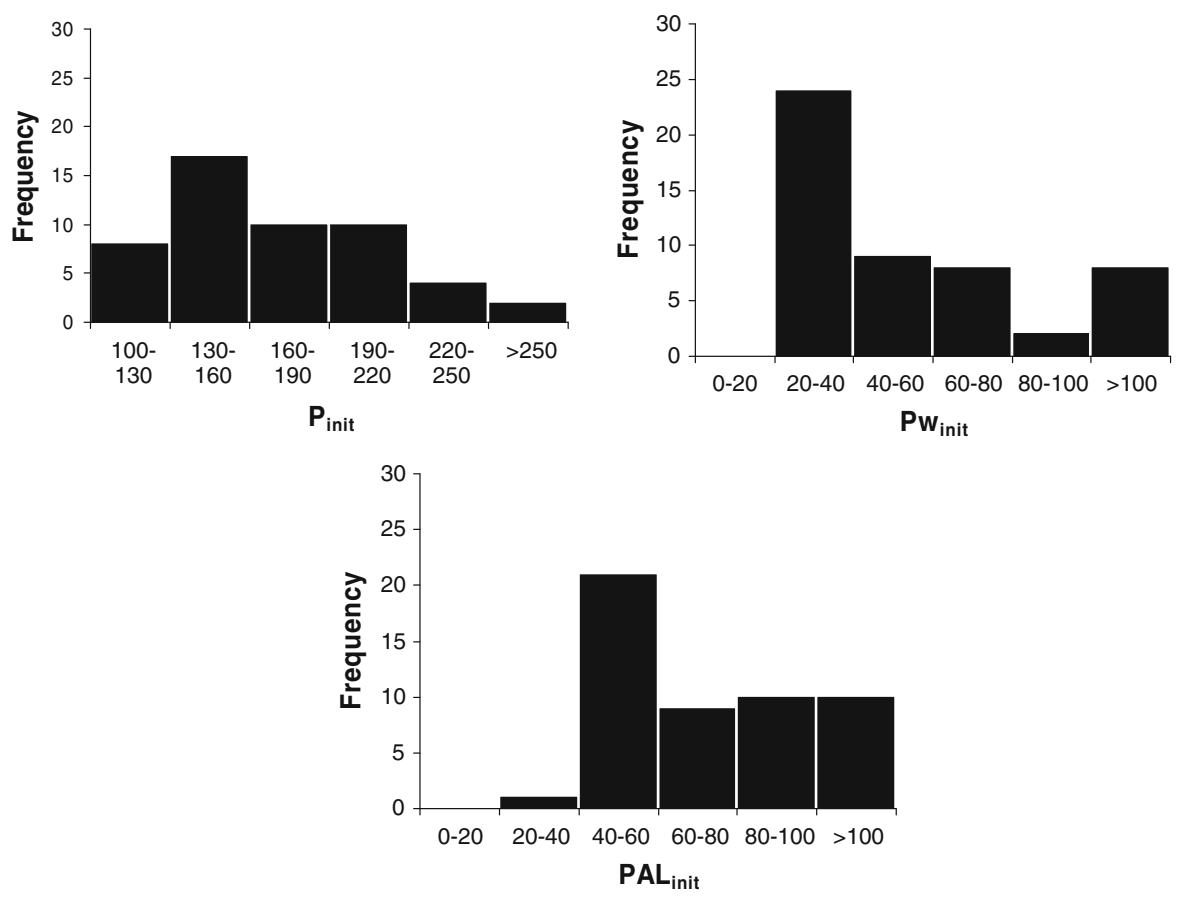

Fig. 1 Distribution of total soil-P and plant-available $\mathrm{P}$ in the layer $0-0.2 \mathrm{~m}$, observed in $1989\left(\mathrm{P}_{\text {init }}, \mathrm{Pw}_{\text {ini }}\right.$ and $\mathrm{P}-\mathrm{Al}_{\text {init }}$ 
Table 4 Development over time of $\mathrm{P}$ surplus $\left(\mathrm{kg} \mathrm{ha}^{-1}\right.$ year $^{-1}$ ), total soil-P, Pw, P-Al, crop P uptake and dry matter (DM) yield $\left(\mathrm{Mg} \mathrm{ha}^{-1}\right)$ and $\mathrm{P}$ concentration in groundwater $\left(\mathrm{mg} \mathrm{l}^{-1}\right)$ at 'De Marke'; means for the whole farm

\begin{tabular}{|c|c|c|c|c|c|c|c|}
\hline \multirow[t]{2}{*}{ Year } & \multirow[t]{2}{*}{ Surplus } & \multicolumn{3}{|c|}{$\mathrm{P}$ status } & \multicolumn{2}{|c|}{$\begin{array}{l}\text { Crop uptake/ } \\
\text { yield }\end{array}$} & \multirow[t]{2}{*}{$\mathrm{P}$ groundwater } \\
\hline & & $\mathrm{P}$ & $\mathrm{Pw}$ & P-Al & $\mathrm{P}$ & $\mathrm{DM}$ & \\
\hline 1989 & - & 169 & 57 & 75 & - & - & 0.04 \\
\hline 1993 & 0 & - & - & - & 33 & 11.1 & 0.01 \\
\hline 1994 & 6 & 165 & 49 & 69 & 34 & 9.6 & 0.01 \\
\hline 1995 & 0 & 166 & 42 & 64 & 28 & 9.1 & 0.02 \\
\hline 1996 & 1 & 162 & 44 & 65 & 26 & 9.4 & 0.02 \\
\hline 1997 & 1 & 164 & 44 & 65 & 29 & 10.6 & 0.10 \\
\hline 1998 & 1 & 160 & 48 & 61 & 29 & 9.2 & 0.02 \\
\hline 1999 & 4 & 161 & 45 & 65 & 32 & 10.6 & 0.03 \\
\hline 2000 & -4 & 162 & 38 & 57 & 36 & 11.9 & 0.02 \\
\hline 2001 & -7 & 158 & 46 & 63 & 36 & 11.9 & 0.04 \\
\hline 2002 & -2 & 151 & 47 & 63 & 34 & 11.7 & 0.02 \\
\hline 2003 & -4 & 160 & 46 & 60 & 28 & 9.8 & 0.04 \\
\hline 2004 & -4 & 159 & 41 & 62 & 33 & 10.9 & 0.02 \\
\hline 2005 & 1 & 154 & 38 & 61 & 33 & 11.1 & 0.03 \\
\hline 2006 & -2 & 142 & 42 & 56 & 28 & 9.4 & 0.02 \\
\hline
\end{tabular}

At the farm scale, annual $\mathrm{P}$ surplus of the soil varied from -7 to $6 \mathrm{~kg} \mathrm{ha}^{-1}$, with a long-term average of $-1 \mathrm{~kg} \mathrm{ha}^{-1}$ (Table 4). Since the application of $\mathrm{P}$ equilibrium fertilization, total soil-P, $\mathrm{Pw}$ and $\mathrm{P}-\mathrm{Al}$ all decreased: $\mathrm{Pw}$ by $26 \%$ (the value in 2006 as compared to the initial value), P-Al by $25 \%$ and total soil-P by $16 \%$. Hence, plant-available $\mathrm{P}$ decreased more strongly than total soil-P.

Table 5 shows the $\mathrm{P}$ status in the upper topsoil for the different land use types (each subjected to P-equilibrium fertilization). The results refer only to the period 2000-2006, because land use effects were expected to become significant some years after the start of P-equilibrium fertilization, while the results

Table 5 Estimates of Pw, P-Al and total soil-P in permanent grassland (Pg), Rot I and Rot II; means of 2000-2006 of plots corrected for $\mathrm{Pwi}_{\text {nit }}, \mathrm{P}-\mathrm{Al}_{\text {init }}, \mathrm{P}_{\text {init }}$ (see text for explanation)

\begin{tabular}{lrrr}
\hline & \multicolumn{1}{l}{ Pg } & \multicolumn{1}{l}{ Rot I } & \multicolumn{1}{c}{ Rot II } \\
\hline Pw & $38(2.2)$ & $43(1.2)$ & $45(1.8)$ \\
P-Al & $60(2.5)$ & $63(1.4)$ & $62(2.0)$ \\
Total soil-P & $153(4.8)$ & $157(2.8)$ & $152(3.9)$ \\
\hline
\end{tabular}

Numbers in brackets are standard errors of the earlier years would mainly reflect the initial soil-P status. Pw was lower under permanent grassland than under Rot I and Rot II. Trends for P-Al and total soil-P were similar, but differences were not significant.

The average rate of decline (units per year) in total soil-P, Pw and $\mathrm{P}-\mathrm{Al}$ in the various plots decreased with decreasing initial values (Fig. 2). Total soil-P hardly changed in plots with low initial values $\left(\mathrm{P}_{\text {init }}\right.$ range 100-130). Similarly, Pw and P-Al did not tend to decrease in plots with $\mathrm{Pw}_{\text {init }}$ of $20-30$ and $\mathrm{P}-\mathrm{Al}_{\text {init }}$ of 30-40, respectively (Fig. 2). The rates of decline in total soil-P, Pw and P-Al can accurately be described as simple linear functions of their initial values.

For most plots, the dynamics of total soil-P could be accurately described as a linear function of time. Non-linear regression did not result in a better fit. For most plots with a high initial-P status, however, the dynamics of $\mathrm{Pw}$ and $\mathrm{P}-\mathrm{Al}$ could be described more accurately by an exponential function, indicating that the rate of decline in those plots tended to level off.

Crop yield

At the farm scale, crop P uptake varied from 26 to $36 \mathrm{~kg} \mathrm{ha}^{-1}$, but $\mathrm{P}$ uptake was not correlated with the development of $\mathrm{P}$ status and did not show any trend over the research period (Table 4). The same was observed for dry matter yield. Dry matter yield was positively correlated with $\mathrm{P}$ uptake (Table 4).

In Fig. 3, dry matter yields of maize and ley are plotted as a function of the $\mathrm{P}$ status of the upper topsoil ( $\mathrm{Pw}$ for maize and $\mathrm{P}-\mathrm{Al}$ for ley). The yields are clustered according to weather types with low (WT1), normal (WT2) and high production (WT3) potential. Dry matter yields of maize and ley did not show a significant correlation with the $\mathrm{P}$ status of the upper topsoil. This was neither the case when the distinction between weather types was not made. Dry matter yield of maize, however, tended to be positively correlated with $\mathrm{Pw}$ in WT2 and WT3 years, and negatively in WT1 years (Fig. 3). Dry matter yields of ley were highly variable, irrespective of the value of P-Al, and tended to be positively correlated with P-Al in WT3 years, not correlated in WT2 years and negatively correlated in WT1 years (Fig. 3). Correlations between dry matter yield and P$\mathrm{Al}$ in permanent grassland (not shown) were similar to those in ley. 
Fig. 2 Average rate of decline (units per year) in total soil-P, Pw and $\mathrm{P}-\mathrm{Al}$ over the period 1989-2006, as a function of their initial value

Fig. 3 Relation between $\mathrm{Pw}$ and dry matter yield $\left(\mathrm{kg} \mathrm{ha}^{-1}\right)$ of silage maize and relation between $\mathrm{P}-\mathrm{Al}$ and dry matter yield of ley in low (WT1), normal (WT2) and high (WT3) production potential years

Fig. 4 Relation between $\mathrm{Pw}$ and $\mathrm{P}$ uptake $\left(\mathrm{kg} \mathrm{ha}^{-1}\right)$ by silage maize and relation between $\mathrm{P}-\mathrm{Al}$ and $\mathrm{P}$ uptake by ley in years with low (WT1), average (WT2) and high (WT3) production potential conditions, respectively
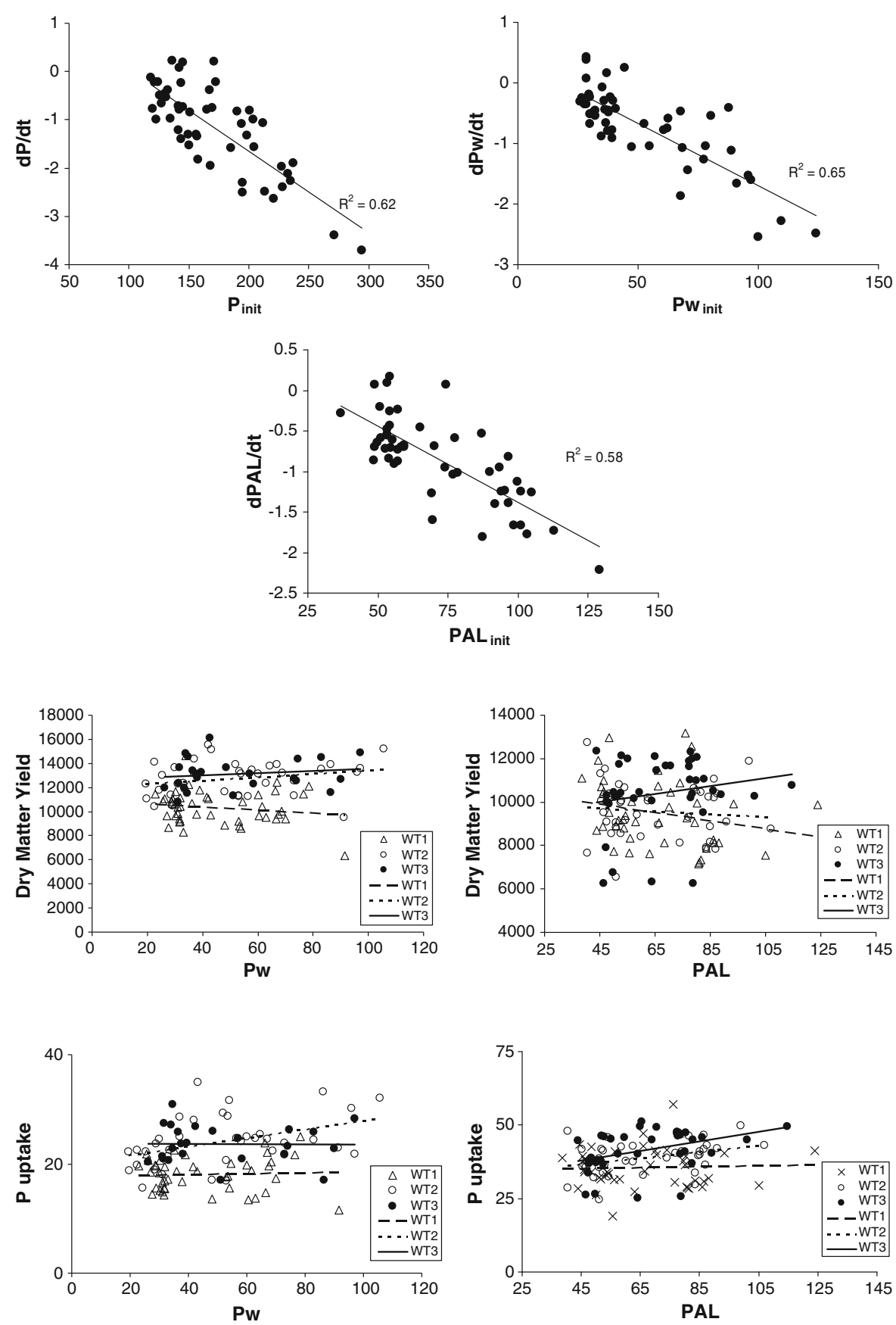

In Fig. 4, P uptake by maize and ley is plotted as a function of the $\mathrm{P}$ status of the upper topsoil ( $\mathrm{Pw}$ for maize and $\mathrm{P}-\mathrm{Al}$ for ley). $\mathrm{P}$ uptake by maize and ley was not correlated with soil-P status when no distinction was made between weather types. There was, however, a positive correlation between $\mathrm{P}$ uptake by maize and $\mathrm{Pw}$ in WT2 years. $\mathrm{P}$ uptake by ley correlated positively with P-Al in WT2 and WT3 years (Fig. 4). There was no significant correlation between $\mathrm{P}$ uptake by permanent grassland and $\mathrm{P}-\mathrm{Al}$ (data not shown).

The relations between $\mathrm{N}$ uptake by maize and grass and soil-P status (data not shown) were similar to those between dry matter yields and soil-P status. 
The N/P ratios in maize and grass dry matter were on average 7.1 (with a variation from 4.0 to 10.4). The ratios did not show any correlation with the $\mathrm{P}$ status of the topsoil.

P losses to the lower topsoil, subsoil and groundwater

For the 31 plots selected for multi-layer sampling, total soil-P in the upper topsoil declined by 1.5 units $\left(17 \mathrm{~kg} \mathrm{P} \mathrm{ha}^{-1}\right.$ ) per year (at a bulk density of $1,300 \mathrm{~kg} \mathrm{~m}^{-3}, 1$ unit of total soil-P is equal to $11,4 \mathrm{~kg}$ P in a soil layer of $0.2 \mathrm{~m}$ ). In the lower topsoil, total soil-P increased by 1.4 units $\left(16 \mathrm{~kg} \mathrm{P} \mathrm{ha}^{-1}\right)$ per year, and in the subsoil it decreased by 0.3 units (3.4 kg P ha ${ }^{-1}$ ) per year. Apparently, the decrease in $\mathrm{P}$ in the top layer practically equals the accumulation in the 0.2-0.4 m layer (Fig. 5). For individual plots, no significant correlation was observed between the change in total soil-P in the upper topsoil and the change in the lower topsoil and the subsoil (Fig. 6). For most plots, a decline in total soil-P in the upper topsoil coincided with an increase in the lower topsoil. However, several plots showed a decline in both, the upper and the lower topsoil, as well as in the subsoil.

At the farm scale, the $\mathrm{P}$ concentration in groundwater (1-3 $\mathrm{m}$ below soil surface) fluctuated over time, but did not show a clear trend over the research period. Consequently, the $\mathrm{P}$ concentration in the groundwater was not correlated to the gradually declining P status of the soil (Table 4). It should be noted that the $\mathrm{P}$ concentration was well below the target level of $0.15 \mathrm{mg} \mathrm{l}^{-1}$.

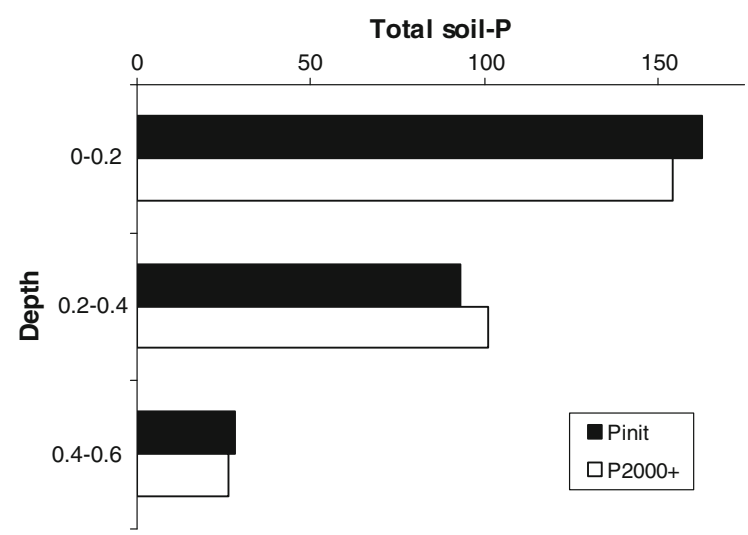

Fig. 5 Initial total soil-P $\left(\mathrm{P}_{\text {init }}\right)$ and means of 2000-2004 $(\mathrm{P} 2000+)$ in the layers $0-0.2,0.2-0.4$ and $0.4-0.6 \mathrm{~m}$

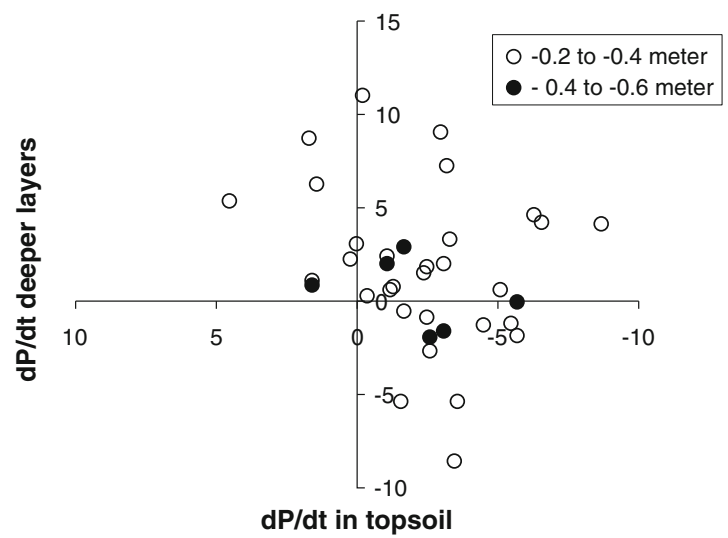

Fig. 6 Relation between the average annual rate of change in total soil-P in the topsoil $(0-0.2 \mathrm{~m})$ and that in the sub-soil $(0.2-0.6 \mathrm{~m})$ for individual plots during the period 1991-2004

In Fig. 7, the $\mathrm{P}$ concentration in the upper metre of groundwater is plotted as a function of Pw. Since the groundwater level varied in time and space, and the groundwater samples were collected from the upper metre of groundwater, sampling depth corresponds roughly to the groundwater level at the moment of sampling. To prevent entanglement of effects of groundwater depth and $\mathrm{Pw}$, the data in Fig. 7 are presented for different groundwater level classes. P concentration in the upper metre of groundwater was not correlated to $\mathrm{Pw}$ in the upper topsoil at any of the groundwater levels. Occasionally, higher P concentrations were found when the groundwater level was shallower than $2 \mathrm{~m}$ below the soil surface, but even in those situations, $\mathrm{P}$ concentrations in the groundwater were not correlated to $\mathrm{Pw}$ in the upper topsoil. The combination of shallow groundwater depth and relatively high $\mathrm{P}$ concentrations was observed particularly in 1998 (Fig. 7), when precipitation in early spring was extremely high. Results for total soil-P and $\mathrm{P}-\mathrm{Al}$ were similar to those presented for $\mathrm{Pw}$.

\section{Discussion}

Development of soil-P status

From Fig. 2 it can be concluded that P-equilibrium fertilization leads to a gradual decline in total soil-P, $\mathrm{Pw}$ and $\mathrm{P}-\mathrm{Al}$ values in the upper topsoil, with average rates of decline proportional to their initial values. Consequently, in the upper topsoil, total soil-P, $\mathrm{Pw}$ 

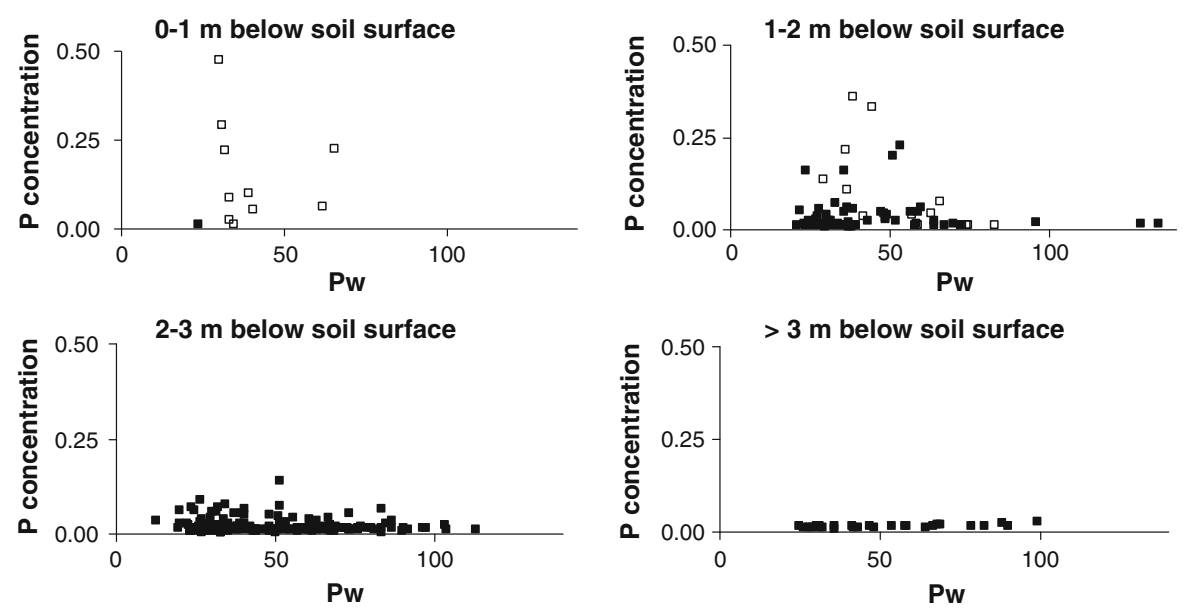

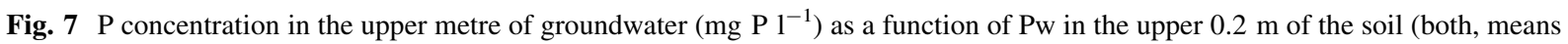
per field), for different groundwater depths. Open squares refer to 1998 , black squares to all other years

and $\mathrm{P}-\mathrm{Al}$ were more or less stable in the fields with low initial status, while these low values were approached in fields with high initial values. These values, therefore, provide an indication of the equilibrium-P status in the topsoil that will be attained after long-term P-equilibrium fertilization. Thus, we may anticipate an equilibrium total soil-P of about 120, an equilibrium $\mathrm{Pw}$ of about 20 and an equilibrium $\mathrm{P}-\mathrm{Al}$ of about 45 . These values of plantavailable $\mathrm{P}$ are somewhat higher than those predicted by Del Campillo et al. (1999), based on modelling. They explored the dynamics of $\mathrm{Pw}$ on farmland in a scenario where excessive $\mathrm{P}$ fertilization was followed by $\mathrm{P}$-equilibrium fertilization. In that scenario, $\mathrm{Pw}$ declined to 13 for soils with a normal P-binding capacity and lower for soils with a low P-binding capacity. The difference between our results and those of Del Campillo et al. (1999) may be associated with: (1) a higher P-binding capacity at 'De Marke' than assumed in the scenarios (a high binding capacity is associated with a high equilibrium level of available P; Van der Zee and Van Riemsdijk 1988), (2) effects of crop rotation that are not accounted for in the chemical models used (as will be discussed below).

The decrease in $\mathrm{Pw}$ in permanent grassland was stronger than in Rot I and Rot II and the same tendency was found for P-Al (Table 5). Apparently, in the crop rotations a larger proportion of the total $\mathrm{P}$ pool was available for plant uptake. In the literature, stimulating effects of land use and soil management on $\mathrm{P}$ availability have been ascribed to (1) the release of root exudates by crops, e.g. lupine (Kahm et al. 1999; Horst et al. 2001; El Dessougi et al. 2003) and rape (Hoffland et al. 1992), (2) effects of soil fauna (Breure et al. 2004) such as bioturbation or mycorhizal activity, often associated with minimum tillage management, (3) the use of deep rooting crops, such as tree species that can acquire $\mathrm{P}$ from deep soil layers (Breman and Kessler 1995) and (4) the return of plant residues to build up a P pool that is bound to organic matter (Kabengi et al. 2003; El Dessougi et al. 2003). None of these explanations logically applies to our situation. In our cropping scheme, the stimulating root exudates should have been produced by maize and to a lesser extent small grains (triticale, wheat), but notably maize is not renowned for stimulating $\mathrm{P}$ mobilization to a larger extent than grass (Kahm et al. 2002). Moreover, significant effects of root exudates have been observed particularly in extensive cropping systems with low soil-P levels and low $\mathrm{P}$ inputs. Concerning (2), at 'De Marke', the activity of soil fauna is lower in Rot I and Rot II than in permanent grassland. With respect to (3), at 'De Marke', all crops have a similar rooting depth due to the sharp boundary between the upper, relatively fertile, rooting zone of $0.3-0.4 \mathrm{~m}$ and the underlying layer of yellow sand. Concerning (4), calculations using crop-specific default values indicate that the return flow of plant organic matter is higher in permanent grassland than in Rot I and Rot II (Verloop and Van Keulen 2007). Presumably, in the 
current study, the stimulating effect of crop rotation on $\mathrm{P}$ availability is the result of ploughing. Perturbation of the topsoil through ploughing may mobilize $\mathrm{P}$ that is bound to organic matter and/or metal oxides. This implies that ploughing, associated with crop rotation, could be an important practical measure to maintain soil-P fertility on farms that have to apply P-equilibrium fertilization. This, however, holds only in flat areas. In hilly areas, ploughing may induce $\mathrm{P}$ runoff and hence loss of available $\mathrm{P}$ from the soil, particularly in the period between ploughing and the start of growth of the subsequent crops when the soil is bare (Heathwaite et al. 1999).

\section{Crop yields}

At farm scale, $\mathrm{P}$ uptake and dry matter yields were positively correlated. In 'normal' field trials, with $\mathrm{P}$ supply as the variable factor, this might be interpreted as an effect of $\mathrm{P}$ on crop development. In the current study, however, the opposite might be the case: an effect of crop development on P uptake, because (1) we hardly observe an effect of P supply (as indicated by soil-P status) on P uptake and (2) N:P ratios in crops do not suggest any $\mathrm{P}$ limitation.

At farm scale, no significant effects were observed of soil-P status on crop $\mathrm{P}$ and $\mathrm{N}$ uptake and crop dry matter yield (Table 4). This was neither the case when the data were differentiated in low, normal and high production potential weather types (Figs. 3, 4). The temporal variability in crop nutrient uptake and crop yield is high, particularly for grass, but this is likely to be related to other factors than $\mathrm{P}$ availability, such as intensity of grazing, age of the sward and/or variations in cutting frequency. Moreover, the observed tendencies in the relations between soil-P status on the one hand and $\mathrm{P}$ uptake and crop yield on the other, were not consistent. We expected that a low soil-P status would limit yields, particularly when the production potential is high, but this occurred only in the ley. Apparently, at 'De Marke', $\mathrm{P}$ limitation was almost absent. This conclusion is supported by the low N:P ratio in the crops (Penning de Vries et al. 1980; Koerselman and Meuleman 1996). The ratio of the $\mathrm{N}$ and $\mathrm{P}$ contents in plant tissue is an indication for the limitation of plant growth by either $\mathrm{N}$ or $\mathrm{P}$ : at $\mathrm{N}: \mathrm{P}$ ratios $>16, \mathrm{P}$ is the main limiting nutrient and at $\mathrm{N}: \mathrm{P}$ ratios $<16$, it is $\mathrm{N}$ (Koerselman and Meuleman 1996). In the current study, the N:P ratio did not exceed 11, indicating that $\mathrm{N}$ is the main limiting nutrient for all fields and in all weather types. This is plausible, since at 'De Marke', N is restrictively applied to prevent $\mathrm{N}$ losses. Hence, also in fields with a soil-P status at or close to the equilibrium value, $\mathrm{P}$ limitation is not likely. This finding is in agreement with insights formalized in Dutch fertilizer recommendations for grassland, since the equilibrium $\mathrm{P}-\mathrm{Al}$ value derived from our research corresponds to the level considered sufficient for optimum grassland production (Anonymous 2002). For maize, however, the equilibrium Pw value (20) is 10 units below the level considered necessary for optimum production (Van Dijk 2003).

P losses to lower topsoil, subsoil and groundwater

From 1989 to 2006, total soil-P in the upper topsoil declined by 27 units (Table 4) which is equivalent to $17 \mathrm{~kg} \mathrm{P} \mathrm{ha}^{-1}$ year $^{-1}$. With a net withdrawal from the fields (supply minus export in crop products) of $1 \mathrm{~kg} \mathrm{P} \mathrm{ha}^{-1}$ year $^{-1}$, average 'loss' of $\mathrm{P}$ would be $16 \mathrm{~kg} \mathrm{ha}^{-1}$ year $^{-1}$. Results of groundwater monitoring indicate that leaching to groundwater (depth 1$3 \mathrm{~m}$ below the soil surface) was negligible. In general, $\mathrm{P}$ concentrations in groundwater were far below $0.15 \mathrm{mg}^{-1}$, at an annual precipitation surplus of $300 \mathrm{~mm}$, equivalent to a $\mathrm{P}$ flux of about $0.5 \mathrm{~kg} \mathrm{ha}^{-1}$ year $^{-1}$. It can thus be concluded that $\mathrm{P}$ must have moved from the upper topsoil to the lower topsoil and the subsoil, but not deeper than $0.6 \mathrm{~m}$ below soil surface. This is illustrated by the developments in $\mathrm{P}$ contents in the different soil layers (difference between the initial contents and the means of 2000-2004; Fig. 5): P accumulation in the deeper layers practically equalled $\mathrm{P}$ depletion in the upper topsoil. The lack of significant correlation between $\mathrm{P}$ depletion in the upper topsoil and $\mathrm{P}$ accumulation in the lower topsoil and subsoil per plot (Fig. 6) may be associated with the inherent soil heterogeneity. The anticipated decrease in total soil-P in the upper topsoil from the present level (142) to the equilibrium level (120) is equivalent to a $\mathrm{P}$ 'loss' from the top layer of about $250 \mathrm{~kg} \mathrm{ha}^{-1}$. This amount will be transported to deeper layers after the introduction of P-equilibrium fertilization.

The analysis of $\mathrm{P}$ leaching in situations with high and low groundwater levels does not suggest any effect of soil-P status on $\mathrm{P}$ leaching. High $\mathrm{P}$ concentrations were observed more frequently 
in situations with a shallow groundwater table than in situations with a deep groundwater table. The risk of $\mathrm{P}$ leaching on free draining sandy soils seems to be determined by groundwater depth rather than by soil$\mathrm{P}$ status. This is in agreement with the known mechanisms of $\mathrm{P}$ binding to soil. Both, in the top layer and in the subsoil, P can be immobilized by Feand Al-(hydr)oxides (Freese et al. 1992). In the situation of shallow groundwater levels, however, these (hydr)oxides are (partially) dissolved, leading to release of P. Hence, transport of $\mathrm{P}$ to the subsoil may result in an increased risk of $\mathrm{P}$ leaching to groundwater. Soil-P mining by applying less $\mathrm{P}$ than P-equilibrium fertilization may be an appropriate strategy to reduce risks in the long term, but management of groundwater levels seems crucial to reduce risks of $\mathrm{P}$ leaching in the short term.

\section{Conclusions}

It is to be expected that future legislation on nutrient management will force farmers to apply P-equilibrium fertilization. The results obtained on dry sandy soil suggest that P-equilibrium fertilization can be compatible with efficient crop production. Particularly on P-rich soils, P-equilibrium fertilization will lead to a decline in total-P content in the upper $0.2 \mathrm{~m}$ of soil. However, continuation of P-equilibrium fertilization will result in an equilibrium soil-P status with a total soil-P content of $120 \mathrm{mg} \mathrm{P}_{2} \mathrm{O}_{5}$ per $100 \mathrm{~g}$ dry soil, a $\mathrm{Pw}$ value of $20 \mathrm{mg} \mathrm{P}_{2} \mathrm{O}_{5}$ per $\mathrm{dm}^{3}$ soil and a $\mathrm{P}-\mathrm{Al}$ value of $45 \mathrm{mg} \mathrm{P}_{2} \mathrm{O}_{5}$ per $100 \mathrm{~g}$ dry soil. A crop rotation with maize, ley and wheat/triticale resulted in higher values for crop-available $\mathrm{P}$ in the soil than permanent grassland, which is probably caused by ploughing. Ploughing, associated with crop rotation, might thus be an adequate strategy to prevent a strong decline in soil$\mathrm{P}$ status when P-equilibrium fertilization has to be applied. Soil-P availability did not affect dry matter production and $\mathrm{P}$ and $\mathrm{N}$ uptake by maize and grass over the full range of values, including those corresponding to the equilibrium status. Hence, P-equilibrium fertilization is not likely to affect crop production as is often presumed, provided that appropriate crop and nutrient management practices are implemented. Negligible P concentrations were detected in the upper groundwater (at depths of 1-3 m), so the observed loss of P from the upper topsoil must have resulted in immobilization in the lower topsoil or the subsoil. $\mathrm{P}$ concentration in groundwater was not correlated to soil-P status. Actual risks of $\mathrm{P}$ leaching to groundwater seem to be determined by groundwater level rather than by soil$\mathrm{P}$ status. Mining of $\mathrm{P}$ from P-enriched soils may be required to prevent $\mathrm{P}$ leaching to groundwater in the long term.

Open Access This article is distributed under the terms of the Creative Commons Attribution Noncommercial License which permits any noncommercial use, distribution, and reproduction in any medium, provided the original author(s) and source are credited.

\section{References}

Aarts HFM (2000) Resource management in a 'De Marke' dairy farming system. Ph.D. Thesis, Wageningen Agricultural University, Wageningen, The Netherlands

Aarts HFM, Biewinga EE, Van Keulen H (1992) Dairy faming systems based on efficient nutrient management. Neth $\mathbf{J}$ Agric Sci 40:285-299

Aarts HFM, Habekotté B, Van Keulen H (2000) Phosphorus (P) management in the 'De Marke' dairy farming system. Nutr Cycl Agroecosyst 56:219-229

Aarts HFM, Daatselaar CHG, Holshof G (2009) Supply of organic and inorganic fertilizer, efficiency of fertilizer use and production of grassland and maize on dairy farms. Koeien \& Kansen Report nr. 50, Plant Research International Report nr. 208, 112 pp (in Dutch)

Anonymous (2000) Directive 2000/60/EC of the European Parliament and of the Council of 23 October 2000 establishing a framework for the Community action in the field of water policy. Official Journal of the European Communities, 22.12.2000, Brussels, Belgium, pp 1-72

Anonymous (2002) Recommendations for the fertilization of grassland and fodder crops. Adviesbasis Bemesting Grasland en Voedergewassen. Committee for the Fertilization of Grassland and Fodder Crops. Applied Research, Animal Sciences Group, Wageningen, The Netherlands. Available at: www.bemestingsadvies.nl (in Dutch)

Boumans LJM, Fraters B, Van Drecht G (2001) Nitrate in the upper groundwater of 'De Marke' and other farms. Neth J Agric Sci 49:163-177

Breman H, Kessler JJ (1995) Woody plants in agro-ecosystems of semi-arid regions. Adv Ser Agric Sci, vol 23, Springer, Berlin, $340 \mathrm{pp}$

Breure AM, Mulder Ch, Rutgers M, Schouten AJ, Van Wijnen HJ (2004) Belowground biodiversity as an indicator for sustainability of soil use. In: Proc Eur Grassld Fed, Zürich, Switzerland, pp 195-197

Conijn JG (2005) CNGRAS; a dynamic simulation model for grassland management and $\mathrm{C}$ and $\mathrm{N}$ flows at field scale. Report 107, Plant Research International, Wageningen, The Netherlands, 57 pp

Del Campillo MC, Van der Zee SEATM, Torrent J (1999) Modelling long-term phosphorus leaching and changes in 
phosphorus fertility in excessively fertilized acid sandy soils. Eur J Soil Sci 50:391-399

Edwards AC, Withers PJA (1998) Soil phosphorus management and water quality: a UK perspective. Soil Use Manag 14:124-130

El Dessougi H, Zu Dreele A, Claassen N (2003) Growth and phosphorus uptake of maize cultivated alone, in mixed culture with other crops or after incorporation of their residues. J Plant Nutr Soil Sci 166:254-261

Freese D, Van der Zee SEATM, Van Riemsdijk WH (1992) Comparison of different models for phosphate sorption as a function of the iron and aluminum oxides of soils. J Soil Sci 43:729-738

Gallet A, Flisch R, Ryser JP, Frossaard E, Sinaj S (2003) Effect of phosphate fertilization on crop yield and soil phosphorus status. J Plant Nutr Soil Sci 166:568-578

Halberg N (1999) Indicators of resource use and environmental impact for use in a decision aid for Danish livestock farmers. Agric Ecosyst Environ 76:17-30

Haygarth PM, Hephworth L, Jarvis SC (1998) Forms of phosphorus transfer in hydrological pathways from soil under grazed grassland. Eur J Soil Sci 49:65-72

Heathwaite L, Haygarth PM, Dils R (1999) Pathways of phosphorus transport. In: Sharokey AN (ed) Agriculture and phosphorus management. The Chesapeake Bay. Lewis, Boca Raton, pp 107-130

Hoffland E, Van den Boogaard R, Nelemans J, Findenegg G (1992) Biosynthesis and root exudation of citric and malic acids in phosphate-starved rape plants. New Phytol 122:675-680

Hooda PS, Truedsale VW, Edwards AC, Withers PJA, Aitken MN, Miller A, Rendell AR (2001) Manuring and fertilization effects of phosphorus accumulation in soils and potential environmental implications. Adv Environ Res 5:13-21

Horst W, Kahm M, Jibrin JM, Chude VO (2001) Agronomic measures for increasing $\mathrm{P}$ availability to crops. Plant Soil 237:221-223

Hosper H (1997) Clearing lakes: an ecosystem approach to the restoration and management of shallow lakes in the Netherlands. Ph.D. Thesis, Wageningen Agricultural University, Wageningen, The Netherlands, $168 \mathrm{pp}$

Kabengi NJ, Zurayk R, Baalbaki RZ, Ryan J (2003) Phosphorus dynamics and characterization under long-term rotation trial. Comm Soil Sci Plant Anal 34:375-392

Kahm M, Horst WJ, Amer F, Mostafa H, Maier P (1999) Mobilization of soil and fertilizer phosphate by cover crops. Plant Soil 211:19-27

Kahm M, Abdou M, Chude V, Wiesler F, Horst WJ (2002) Mobilization of phosphorus contributes to positive rotational effects of leguminous cover crops on maize grown on soils from northern Nigeria. J Plant Nutr Soil Sci 165:566-572

Koerselman W, Meuleman AFM (1996) The vegetation N:P ratio: a new tool to detect the nature of nutrient limitation. J Appl Ecol 33:1441-1450

Koopmans GF (2004) Characterization, desorption, and mining of phosphorus in noncalcareous sandy soils. Ph.D. Thesis, Wageningen University, Wageningen, The Netherlands. 168 pp

Koopmans GF, Chardon WJ, Ehlert PAI, Dolfing J, Suurs RAA, Oenema O, Van Riemsdijk WH (2004) Phosphorus availability for plant uptake in a phosphorus-enriched noncalcareous sandy soil. J Environ Qual 33(3):965-975

Kronvang B, Vagstad N, Behrendt H, Bøgestrand J, Larsen SE (2007) Phosphorus losses at the catchment scale within Europe: an overview. Soil Use Manag 23(Suppl. 1):104-116

Leigh RA, Johnston AE (1986) An investigation of the usefulness of phosphorus concentrations in tissue water as indicators of the phosphorus status of field grown spring barley. J Agric Sci 107:329-333

Morse D, Head HH, Wilcos CJ, Van Horn HH, Hissem CD, Harris B Jr (1992) Effects of concentration of dietary phosphorus on amount and route of excretion. J Dairy Sci 75(11):3039-3049

Murphy J, Riley JP (1962) A modified single solution method for the determination of phosphate in natural waters. Anal Chim Acta 27:31-36

Neeteson JJ, Schröder JJ, Smit AL, Bos JFFP, Verloop J (2006) Need and opportunities to reduce phosphorus inputs, soil supply and loss from agriculture in the Netherlands. The International Fertiliser Society Proceedings 595, York, $\mathrm{UK}, 23 \mathrm{pp}$

Neyroud JA, Lisscher P (2003) Do different methods used to estimate soil phosphorus availability across Europe give comparable results? J Plant Nutr Soil Sci 166:422-431

Penning de Vries FWT, Krul JM, Van Keulen H (1980) Productivity of Sahelian rangelands in relation to the availability of nitrogen and phosphorus from the soil. In: Rosswall T (ed) Nitrogen cycling in West African ecosystems. SCOPE/UNEP International Nitrogen Unit, Royal Swedish Academy of Sciences, Stockholm, Sweden, pp 95-113

Pfimlin A, Irle A, Mirabal Y (2006) Contribution of the dairy herd to nitrogen and phosphorus surplus at regional scale and risks for water quality. In: Dairy systems and environment in the Atlantic Area; proceedings of the final seminar, Green Dairy Project, Institut d'Elevage, Rennes, 13 December, pp 97-117

Schippers P, Van de Weerd H, De Klein J, De Jong B, Scheffer $M$ (2006) Impacts of agricultural phosphorus use in catchments on shallow lake water quality: about buffers, time delays and equilibria. Sci Total Environ 369:280294

Supit I, Hooijer AA, Van Diepen CA (1994) System description of the WOFOST 6.0 crop simulation model implemented in CGMS. Publication EUR 15956 EN of the Office for Official Publications of the EU, Luxembourg

Syers JK, Johnston AE, Curtin D (2008) Efficiency of soil fertilizer phosphorus use. Reconciling changing concepts of soil phosphorus behaviour with agronomic information. FAO Fertilizer and Plant Nutrition Bulletin 18, FAO, Rome, Italy, 108 pp

Tunney H, Breeuwsma A, Withes P, Ehlert PAI (1997) Phosphorus fertilizer strategies: present and future. In: Tunney H, Carton OT, Brookes PC, Johnston AE (eds) Phosphorus loss from soil to water. CABI, Wallingford, pp 177203

Ulén B, Bechmann M, Fölster J, Jarvie HP, Tunney H (2007) Agriculture as a phosphorus source for eutrophication in the north-west European countries, Norway, Sweden, United Kingdom and Ireland: a review. Soil Use Manag 23(Suppl. 1):5-15 
Valk H, Sebek LBJ (1999) Influence of long-term feeding of limited amounts of phosphorus on dry matter intake, milk production, and body weight of dairy cows. J Dairy Sci 82:2157-2163

Van der Paauw F (1956) Calibration of soil test methods for the determination of phosphate and potash. Plant Soil 8: 105-125

Van der Paauw F (1971) An effective water extraction method for the determination of plant-available soil phosphorus. Plant Soil 34:467-481

Van der Zee SEATM, Van Riemsdijk WH (1988) Model for long-term phosphate reaction kinetics in soil. J Environ Qual 17:35-41

Van Dijk W (2003) Recommendation base for fertilization of arable and outdoor horticultural crops. PPO-Publicatie 307, Lelystad, The Netherlands, 66 pp (in Dutch)

Verloop J, Van Keulen H (2007) Effects of efficient nutrient management on soil organic matter dynamics on a dairy farm on light sandy soil in the Netherlands. In: Chabbi A (ed) Proceedings of the international symposium on organic matter dynamics in agro-ecosystems, Poitier, France. pp 370-371

Verloop J, Boumans LJM, Van Keulen H, Oenema J, Hilhorst GJ, Aarts HFM, Sebek LBJ (2006) Reducing nitrate leaching to groundwater in an intensive dairy farming system. Nutr Cycl Agroecosyst 74:59-74

Von Liebig J (1841) Die organische Chemie und ihre Anwendung im Agrikultur und Physiologie. Vieweg, Braunschweig

Watson CA, Bengtsson H, Ebbesvik M, Loes AL, Myrbeck A, Salomon E, Schröder JJ, Stockdale EA (2002) A review of farm-scale nutrient budgets for organic farms as a tool for management of soil fertility. Soil Use Manag 118:264273 